\title{
Vetiverianines A, B, and C: Sesquiterpenoids from Vetiveria zizanioides Roots
}

Yukiko Matsuo, 'Saori Maeda, Chika Ohba, Haruhiko Fukaya, and Yoshihiro Mimaki,

Tokyo University of Pharmacy and Life Sciences, School of Pharmacy, 1432-1, Horinouchi, Hachioji, Tokyo 192-0392, Japan

p.2 X-ray crystallographic study

p.4 VCD (Vibrational circular dichroism) spectroscopy study

p. $4{ }^{1} \mathrm{H}$ and ${ }^{13} \mathrm{C}$ NMR data of 4

S1. ${ }^{1} \mathrm{H}$ NMR spectrum of the new compd. 1

S2. ${ }^{13} \mathrm{C}$ NMR spectrum of the new compd. 1

S3. ${ }^{1} \mathrm{H}-{ }^{1} \mathrm{H}$ COSY of the new compd. 1

S4. HMBC of the new compd. 1

S5. HMQC of the new compd. 1

S6. NOESY of the new compd. 1

S7. ${ }^{1} \mathrm{H}$ NMR spectrum of the new compd. 2

S8. ${ }^{13} \mathrm{C}$ NMR spectrum of the new compd. 2

S9. ${ }^{1} \mathrm{H}-{ }^{1} \mathrm{H}$ COSY of the new compd. 2

S10. HMBC of the new compd. 2

S11. HMQC of the new compd. 2

S12. NOESY of the new compd. 2

S13. ${ }^{1} \mathrm{H}$ NMR spectrum of the new compd. 3

S14. ${ }^{13} \mathrm{C}$ NMR spectrum of the new compd. 3

S15. ${ }^{1} \mathrm{H}-{ }^{1} \mathrm{H}$ COSY of the new compd. 3

S16. HMBC of the new compd. 3

S17. HMQC of the new compd. 3

S18. NOESY of the new compd. 3

S19. The photograph of plant material 


\section{SUPPORTING INFORMATION}

\section{X-ray crystallographic study}

Recrystallization of 1 was carried out by slow evaporation of the hexane-acetone (1:2) solution at room temperature. A suitable size $(0.21 \times 0.20 \times 0.16 \mathrm{~mm})$ of a crystal for X-ray crystallographic analysis was obtained and the diffraction data was collected at $90 \mathrm{~K}$. A total of 14008 reflections were collected with a scan width of $0.5^{\circ}$ and an exposure time of $3 \mathrm{sec} /$ frame, within $\theta$ range of 2.49 to $25.02^{\circ}$ with the index ranges $-7 \leq h \leq 7,-19 \leq k \leq 19,-33 \leq l \leq 19$. The independent reflections were $5072\left(R_{\text {int }}=0.032\right)$ and the observed reflections with $I>2 \sigma(I)$ were 4594 . The crystal belongs to the orthorhombic and the space group was $P 2{ }_{1} 2_{1} 2_{1}$, with cell dimensions of $a=6.2420(6) \AA, b=16.3290(15) \AA, c=28.076(3) \AA$, and $V=2861.7(5) \AA^{3}, D_{\text {calc }}=1.148 \mathrm{~g} / \mathrm{cm}^{3}, Z=4, F(000)=1096$. The integration and reduction of all data were carried out with the Bruker Suite software package. ${ }^{1)}$ A numerical absorption correction was applied with SADABS. ${ }^{2)}$ The structures were solved by direct methods using SHELXS-97 ${ }^{3)}$ and refined by full-matrix least-squares calculations with SHELXL-97. ${ }^{4)}$ The non-hydrogen atoms were refined anisotropically, and all hydrogen atoms, except for the hydrogen atoms attached to the oxygen atom (O2), were placed in geometrically calculated positions $(\mathrm{C}-\mathrm{H} 0.98 \AA)$ and treated as riding on their parent atoms. The final $R$ indices were $R_{1}=0.0376, w R_{2}=0.0825$ for reflections with $I>2 \sigma(I)$ and $R_{1}=0.0425$, $w R_{2}=0.0851$ for all data. The Flack absolute structure parameter ${ }^{5)}$ was $-0.2(8)$. The $S$ (goodness-of-fit on $F^{2}$ ) value was 1.050 , and the largest residual peak and hole in the final difference map were $0.15 \mathrm{e} / \AA^{3}$ and $-0.17 \mathrm{e} / \AA^{3}$, respectively.

Recrystallization of $\mathbf{2}$ was carried out by slow evaporation of the $\mathrm{MeOH}$ solution at room temperature. A suitable size $(0.25 \times 0.14 \times 0.14 \mathrm{~mm})$ of a crystal for X-ray crystallographic analysis was obtained and the diffraction data was collected at $90 \mathrm{~K}$. A total of 6432 reflections were collected with a scan width of $0.5^{\circ}$ and an exposure time of $3 \mathrm{sec} /$ frame, within $\theta$ range of 2.32 to $25.03^{\circ}$ with the index ranges $-6 \leq h \leq$ $6,-10 \leq k \leq 15,-18 \leq l \leq 20$. The independent reflections were $2325\left(R_{\text {int }}=0.023\right)$ and the observed reflections with $I>2 \sigma(I)$ were 2200 . The crystal belongs to the orthorhombic and the space group was $P 2{ }_{1}{ }_{1} 2{ }_{1}$, with cell dimensions of $a=5.8324(7) \AA, b=12.9306(14) \AA, c=17.550(2) \AA$, and $V=1323.6(3)$ $\AA^{3}, D_{\text {calc }}=1.176 \mathrm{~g} / \mathrm{cm}^{3}, Z=4, F(000)=512$. The non-hydrogen atoms were refined anisotropically, and all hydrogen atoms were placed in geometrically calculated positions $(\mathrm{C}-\mathrm{H} 0.98 \AA)$ and treated as riding on their parent atoms. The final $R$ indices were $R_{1}=0.0304, w R_{2}=0.0763$ for reflections with $I>2 \sigma(I)$ and $R_{1}=0.0325, w R_{2}=0.0775$ for all data. The Flack absolute structure parameter was $-0.3(11)$. The $S$ value was 1.040 , and the largest residual peak and hole in the final difference map were $0.16 \mathrm{e} / \AA^{3}$ and $-0.14 \mathrm{e} / \AA^{3}$, respectively. 
Recrystallization of $\mathbf{3}$ was carried out by slow evaporation of the $\mathrm{MeOH}$ solution at room temperature. A suitable size $(0.32 \times 0.22 \times 0.17 \mathrm{~mm})$ of a crystal for X-ray crystallographic analysis was obtained and the diffraction data was collected at $90 \mathrm{~K}$. A total of 7714 reflections were collected with a scan width of $0.5^{\circ}$ and an exposure time of $3 \mathrm{sec} /$ frame, within $\theta$ range of 1.26 to $27.55^{\circ}$ with the index ranges $-7 \leq h \leq$ $7,-9 \leq k \leq 8,-41 \leq l \leq 24$. The independent reflections were $3020\left(R_{\mathrm{int}}=0.020\right)$ and the observed reflections with $I>2 \sigma(I)$ were 2953. The crystal belongs to the orthorhombic and the space group was $P 2{ }_{1}{ }_{1} 2_{1}$, with cell dimensions of $a=5.6076(5) \AA, b=7.3152(6) \AA, c=32.200(3) \AA$, and $V=1320.87(19)$ $\AA^{3}, D_{\text {calc }}=1.188 \mathrm{~g} / \mathrm{cm}^{3}, Z=4, F(000)=520$. The non-hydrogen atoms were refined anisotropically, and all hydrogen atoms were, except for the hydrogen atoms attached to the oxygen atom $(\mathrm{O} 2)$, placed in geometrically calculated positions $(\mathrm{C}-\mathrm{H} 0.98 \AA)$ and treated as riding on their parent atoms. The final $R$ indices were $R_{1}=0.0331, w R_{2}=0.0860$ for reflections with $I>2 \sigma(I)$ and $R_{1}=0.0338, w R_{2}=0.0868$ for all data. The Flack absolute structure parameter was $-0.0(3)$. The $S$ value was 1.057 , and the largest residual peak and hole in the final difference map were $0.27 \mathrm{e} / \AA^{3}$ and $-0.18 \mathrm{e} / \AA^{3}$, respectively.

The single crystal X-ray diffraction data was collected using a Bruker SMART APEX II CCD diffractometer equipped with a multilayer confocal mirror and a fine-focus rotating anode (Mo $\mathrm{K} \alpha, \lambda=$ $0.71073 \AA$ ) in the phi and omega scan mode with operating at $90 \mathrm{~K}$ by a low temperature device (DX-CS190LD, Japan Thermal Engineering Co.).

Compound 1. $\mathrm{C}_{30} \mathrm{H}_{54} \mathrm{O}_{5}\left[2\left(\mathrm{C}_{15} \mathrm{H}_{26} \mathrm{O}_{2}\right) \mathrm{H}_{2} \mathrm{O}\right], M=494.73,0.21 \times 0.20 \times 0.16 \mathrm{~mm}$, orthorhombic, $P 2{ }_{1} 2_{1} 2_{1}$, $a=6.2420(6) \AA, b=16.3290(15) \AA, c=28.076(3) \AA, V=2861.7(5) \AA^{3}, Z=4, D_{\text {calc }}=1.148 \mathrm{~g} / \mathrm{cm}^{3}, \mu(\mathrm{Mo}$ $\mathrm{K} \alpha)=0.076 \mathrm{~mm}^{-1}, T=90 \mathrm{~K}, 14008$ measured reflections, 5072 independent reflections $\left(R_{\text {int }}=0.032\right)$, 4594 observed reflections with $I>2 \sigma(I), R_{1}=0.0376, w R_{2}=0.0825$ (observed data), $R_{1}=0.0425, w R_{2}=$ 0.0851 (all data), $S=1.050$, Flack parameter $=-0.2(8)$.

Compound 2. $\mathrm{C}_{15} \mathrm{H}_{22} \mathrm{O}_{2}, M=234.33,0.25 \times 0.14 \times 0.14 \mathrm{~mm}$, orthorhombic, P2 ${ }_{1} 2_{1} 2_{1}, a=5.8324(7) \AA, b$ $=12.9306(14) \AA, c=17.550(2) \AA, V=1323.6(3) \AA^{3}, Z=4, D_{\text {calc }}=1.176 \mathrm{~g} / \mathrm{cm}^{3}, \mu(\mathrm{Mo} \mathrm{K} \alpha)=0.76 \mathrm{~mm}^{-1}$, $T=90 \mathrm{~K}, 6432$ measured reflections, 2325 independent reflections $\left(R_{\text {int }}=0.022\right), 2200$ observed reflections with $I>2 \sigma(I), R_{1}=0.0304, w R_{2}=0.0763$ (observed data), $R_{1}=0.0325, w R_{2}=0.0775$ (all data), $S=1.040$, Flack parameter $=-0.3(11)$.

Compound 3. $\mathrm{C}_{15} \mathrm{H}_{24} \mathrm{O}_{2}, M=236.34,0.32 \times 0.22 \times 0.17 \mathrm{~mm}$, orthorhombic, $P 2{ }_{1}{ }_{1}{ }_{2}{ }_{1}, a=5.6076(5) \AA, b$

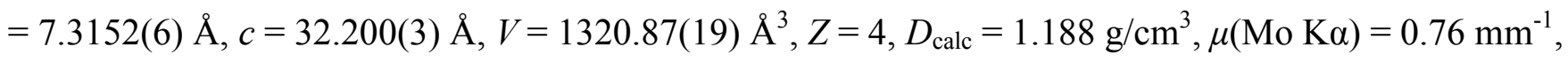
$T=90 \mathrm{~K}, 7712$ measured reflections, 3020 independent reflections $\left(R_{\text {int }}=0.020\right), 2953$ observed reflections with $I>2 \sigma(I), R_{1}=0.0331, w R_{2}=0.0860$ (observed data), $R_{1}=0.0338, w R_{2}=0.0868$ (all data), $S=1.057$, Flack parameter $=-0.0(3)$. 
Crystallographic data for 1-3 have been deposited with the Cambridge Crystallographic Data Centre, under the reference numbers CCDC 1408730, 1408731 and 1408732, respectively. Copies of the data can be obtained, free of charge, on application to the Director, CCDC, 12 Union Road, Cambridge CB21EZ, U.K. (fax+44-(0)-1223-336033 or e-mail: deposit@ccdc.cam.ac.uk).

\section{VCD (Vibrational circular dichroism) spectroscopy study}

The initial coordinates of conformers were determined by using the X-ray study of $\mathbf{1} \mathbf{- 3}$.

Conformation analysis of 1 with $4 S, 5 S, 6 S, 7 S$ and $10 S$ configuration by the Monte Carlo conformational search with MMFF94S force field gave four conformers within $7 \mathrm{kcal} / \mathrm{mol}$ from the global minimum energy conformation. In order to estimate their conformation population, single-point energy calculations were performed for those conformers at the DFT/B3LYP/6-31G (d,p) level. The results indicated that the three lowest energy conformers, 1a -1c were in the relative energy range of 0.05 $\mathrm{kcal} / \mathrm{mol}$ and estimated to contribute $99.9 \%$ of the total population. The geometries of the three conformers were further optimized at the B3PW91/DGDZVP2 level and the calculated relative energy and the Boltzmann populations.

Monte Carlo conformational search of 2 with $4 R, 5 S$, and $7 R$ configuration gave four conformers within $3 \mathrm{kcal} / \mathrm{mol}$ and single-point energy calculations were carried out for those four conformers at the B3LYP/6-31G(d,p) level. The results showed that the energy difference between the lowest energy conformer and the second lowest energy conformer was $1.73 \mathrm{kcal} / \mathrm{mol}$, and that between the lowest energy conformer and the third lowest energy conformer was $2.14 \mathrm{kcal} / \mathrm{mol}$. Thus, the conformational distribution of this lowest energy conformer was estimated to be more than $99.76 \%$ in 2 . The theoretical VCD spectrum of $\mathbf{2}$ was calculated using this lowest energy conformer structure at the B3PW91/DGDZVP2 level.

For conformational searching of $\mathbf{3}$ with $4 R, 5 S$, and $7 R$, five conformers were yield in the first 3.0 $\mathrm{kcal} / \mathrm{mol}$ and were subjected to single-point energy calculation. The resulting three low energy conformers, 3a -3c were in the relative energy range of $2.92 \mathrm{kcal} / \mathrm{mol}$ and estimated to contribute $99.9 \%$ of the total population. The geometries of the three conformers were further optimized and the calculations of the frequencies were performed at the DFT/B3PW91/DGDZVP2 level.

The conformational analysis of $\mathbf{1}, \mathbf{2}$ and $\mathbf{3}$ was performed by a Monte Carlo search with the MMFF94S force field using MacroModel ver. 7.0 software (Schrödinger Inc., Portland, OR). All of the obtained conformers were subjected to single point calculations at the DFT/B3LYP/6-31G(d,p) level. The 
geometric optimization and the calculations of the free energies and the frequencies were performed at the DFT/B3PW91/DGDZVP2 level using Gaussian 09W software (Gaussian, Inc., Wallingford, CT). The calculated VCD spectra were obtained with Lorentzian band shapes of $4 \mathrm{~cm}^{-1}$ half-width at half-height. The frequencies of the calculated spectra were scaled by a factor of 0.98 .

\section{VCD measurements.}

VCD spectra were measured with a Dual-PEM Chiral IR-2X FT-VCD spectrometer (BioTools, Inc., Jupiter, FL) in a $75 \mu \mathrm{m}$ cell with $\mathrm{BaF}_{2}$. Compounds 1-3 were each dissolved in $\mathrm{CDCl}_{3}$ at a concentration of $0.12 \mathrm{M}(3.6 \mathrm{mg} / 150 \mu \mathrm{L}), 0.16 \mathrm{M}(5.7 \mathrm{mg} / 150 \mu \mathrm{L})$, and $0.17 \mathrm{M}(6.1 \mathrm{mg} / 150 \mu \mathrm{L})$, respectively.

\section{References}

1) Bruker Suite, Bruker AXS Inc., Madison, USA, 2008.

2) Sheldrick G. M., SADABS, Bruker AXS area detector scaling and absorption, Version 2008/1, Univ. of Göttingen, 2008.

3) Sheldrick G. M., SHELXS-97, Program for crystal structure solution of crystal structures, Univ. of Göttingen, 1997.

4) Sheldrick G. M., SHELXL-97, Program for crystal structure refinement of crystal structures, Univ. of Göttingen, 1997.

5) Flack H. D., Acta Cryst., A39, 876-881 (1983).

Compound 4: An amorphous solid; $[\alpha]_{\mathrm{D}}^{25}+13.6$ (c 0.28, $\left.\mathrm{CH}_{3} \mathrm{OH}\right) ; \mathrm{IR} v_{\max }\left(\right.$ film) $\mathrm{cm}^{-1}: 3310(\mathrm{OH})$, 2931, $2864(\mathrm{CH}) ;{ }^{1} \mathrm{H}$ NMR $\left(500 \mathrm{MHz}, \mathrm{CDCl}_{3}\right) \delta_{\mathrm{H}} 3.90(1 \mathrm{H}, \mathrm{dd}, J=10.5,10.5 \mathrm{~Hz}, \mathrm{H}-6), 3.32(1 \mathrm{H}, \mathrm{dd}, J=$ 10.9, $3.9 \mathrm{~Hz}, \mathrm{H}-1), 2.18$ (1H, m, H-11), 1.85 (1H, ddd, $J=12.2,3.0,3.0 \mathrm{~Hz}, \mathrm{H}-9 \beta), 1.78$ (1H, dd, $J=9.2$, $3.0 \mathrm{~Hz}, \mathrm{H}-3 \beta), 1.71(1 \mathrm{H}, \mathrm{ddd}, J=9.8,3.9,3.0 \mathrm{~Hz}, \mathrm{H}-2 \beta), 1.60(1 \mathrm{H}$, overlapping, $\mathrm{H}-9 \alpha), 1.57$ (1H, m,

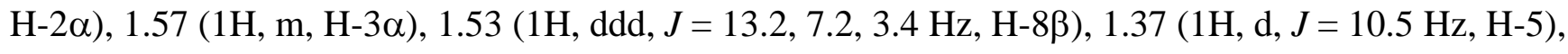
1.35 (1H, s, Me-15), 1.34 (1H, overlapping, H-7), 1.24 (1H, dd, $J=13.2,3.4 \mathrm{~Hz}, \mathrm{H}-8 \alpha), 0.95(1 \mathrm{H}, \mathrm{d}, J=$ $7.5 \mathrm{~Hz}, \mathrm{Me}-12), 0.87(1 \mathrm{H}, \mathrm{d}, J=7.5 \mathrm{~Hz}, \mathrm{Me}-13), 0.86(1 \mathrm{H}, \mathrm{s}, \mathrm{Me}-14) ;{ }^{13} \mathrm{C} \mathrm{NMR}\left(125 \mathrm{MHz}, \mathrm{CDCl}_{3}\right) \delta_{\mathrm{C}}$ 78.8 (C-1), 73.4 (C-4), 70.8 (C-6), 56.1 (C-5), 51.4 (C-7), 40.4 (C-3), 40.3 (C-10), 39.2 (C-9), 28.0 (C-2), 25.4 (C-11), 23.6 (C-15), 21.0 (C-12), 18.3 (C-8), 15.8 (C-13), 13.9 (C-14); HRESITOFMS (m/z: $279.1938[\mathrm{M}+\mathrm{Na}]^{+}$, calcd for $\left.\mathrm{C}_{15} \mathrm{H}_{28} \mathrm{NaO}_{3}: 279.1936\right)$. 
S1. ${ }^{1} \mathrm{H}$ NMR spectrum of the new compd. 1

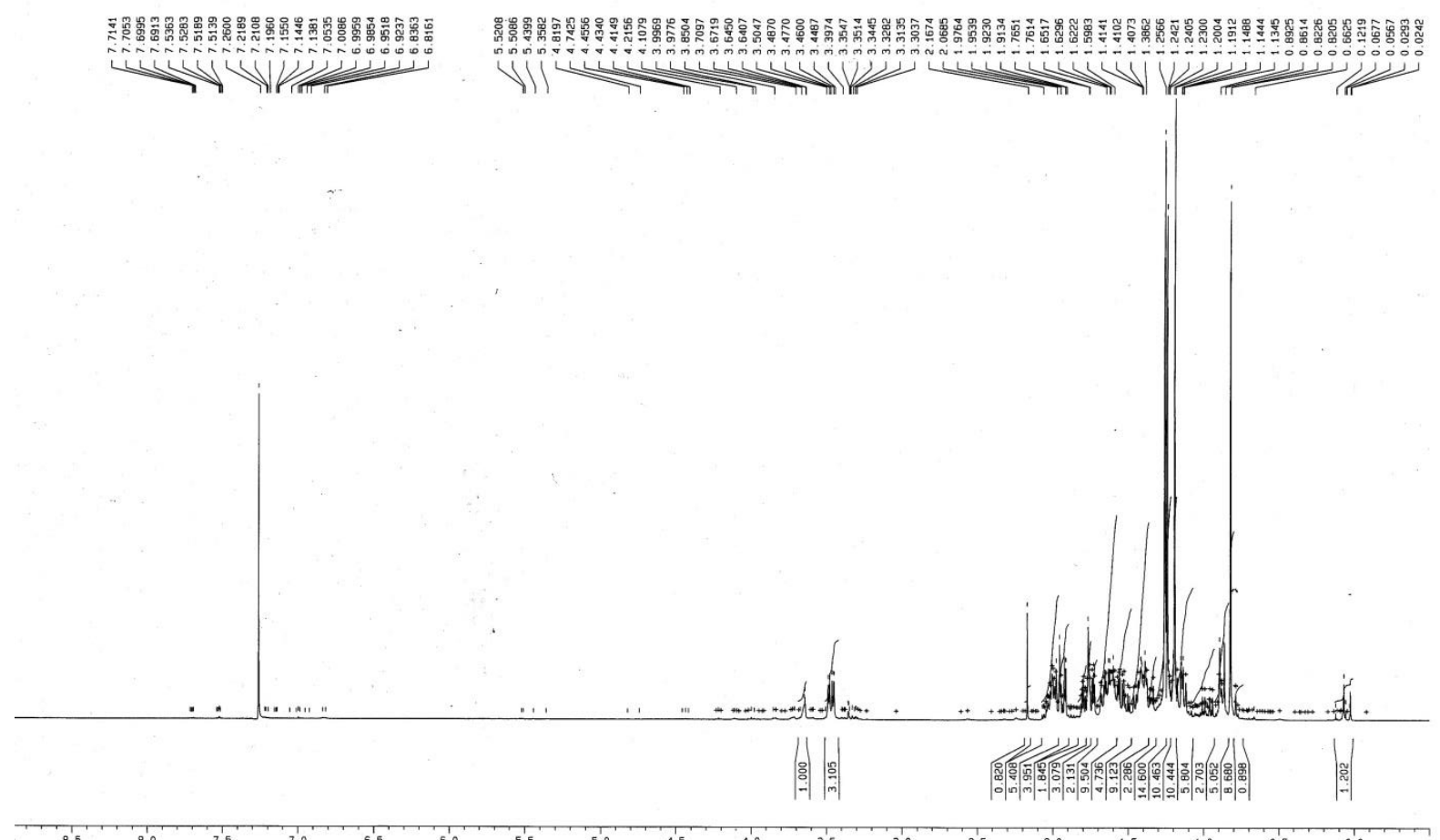

S2. ${ }^{13} \mathrm{C}$ NMR spectrum of the new compd. 1

$\frac{1}{2}$

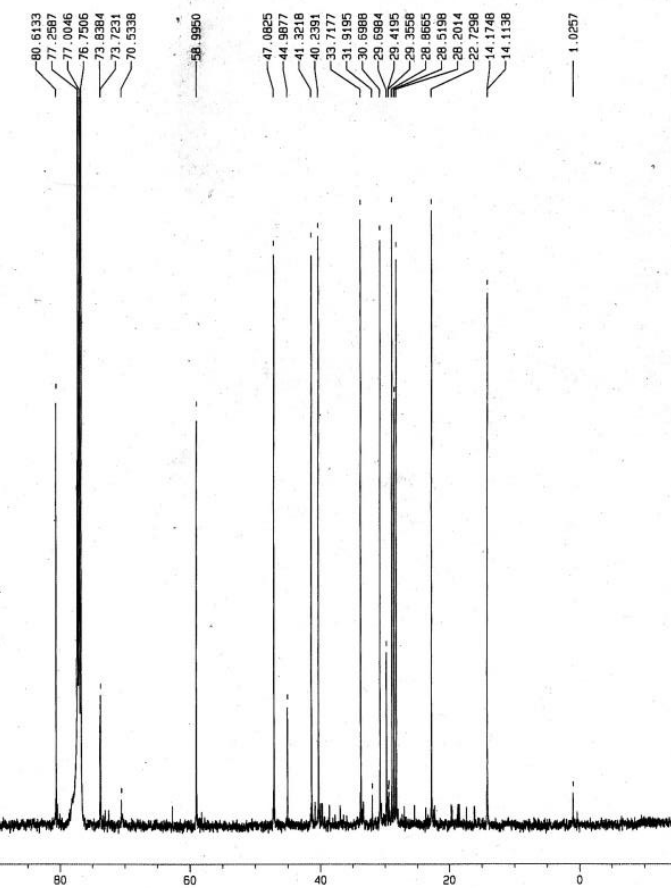



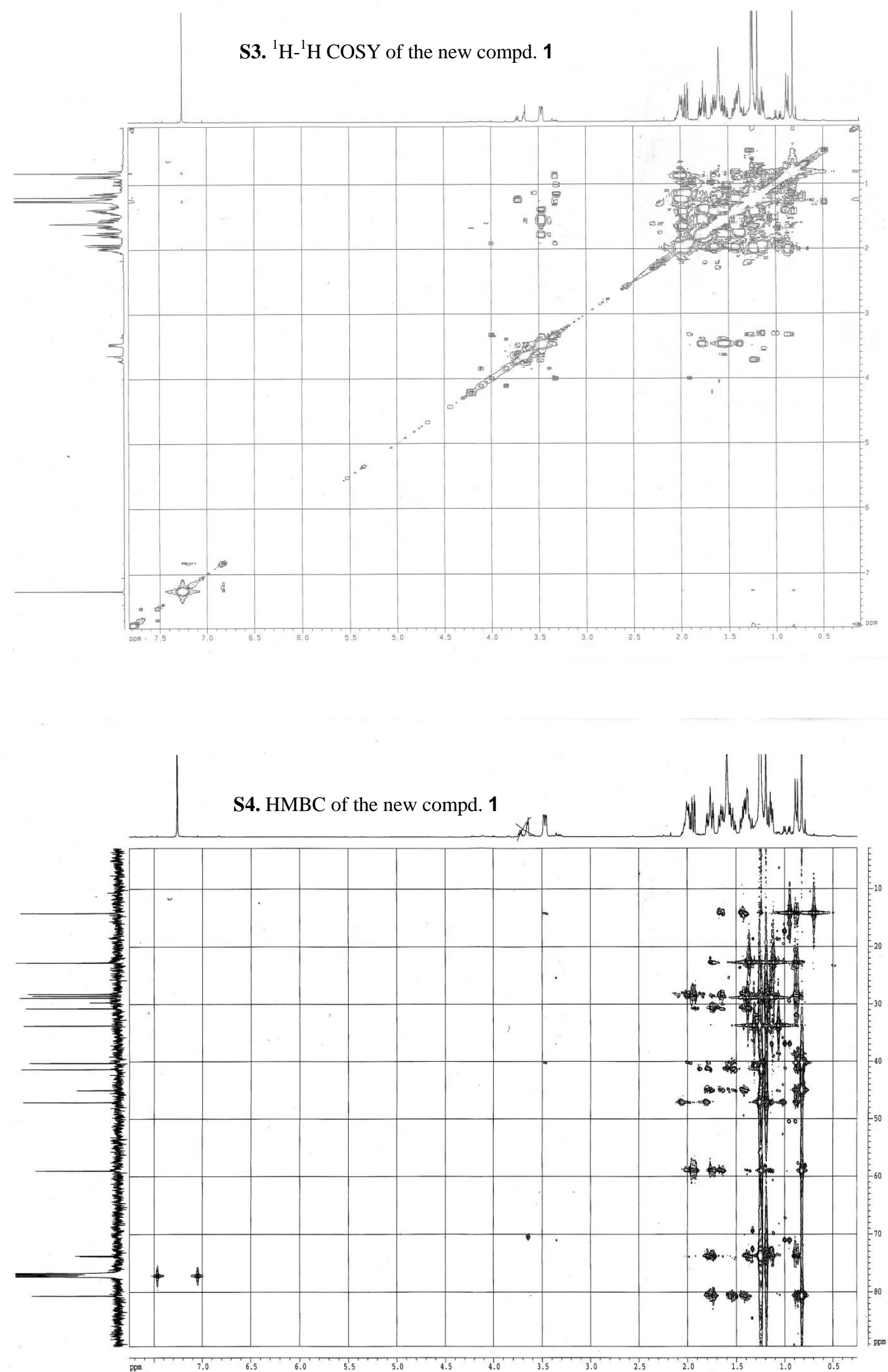

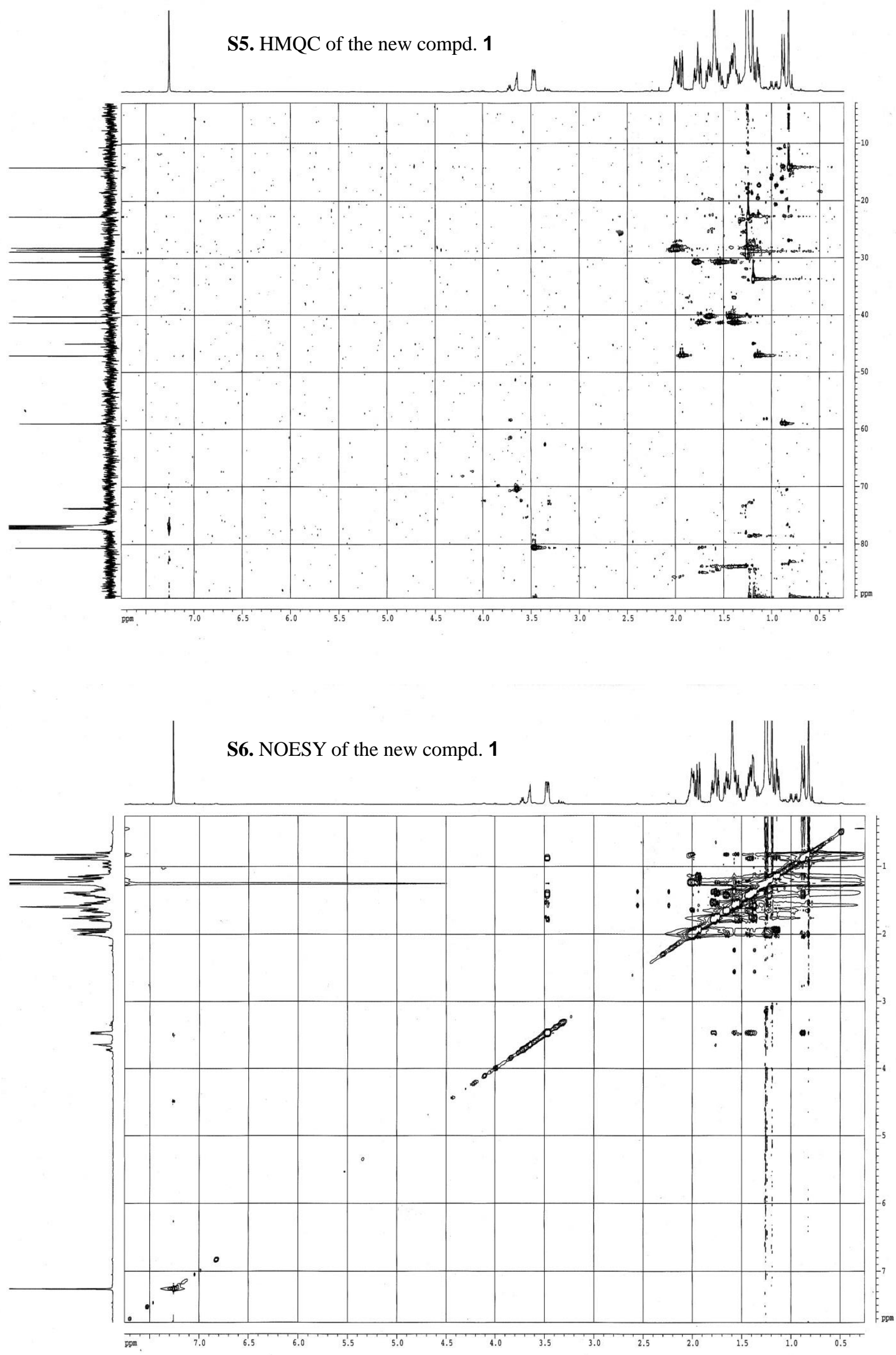
S7. ${ }^{1}$ H NMR spectrum of the new compd. 2

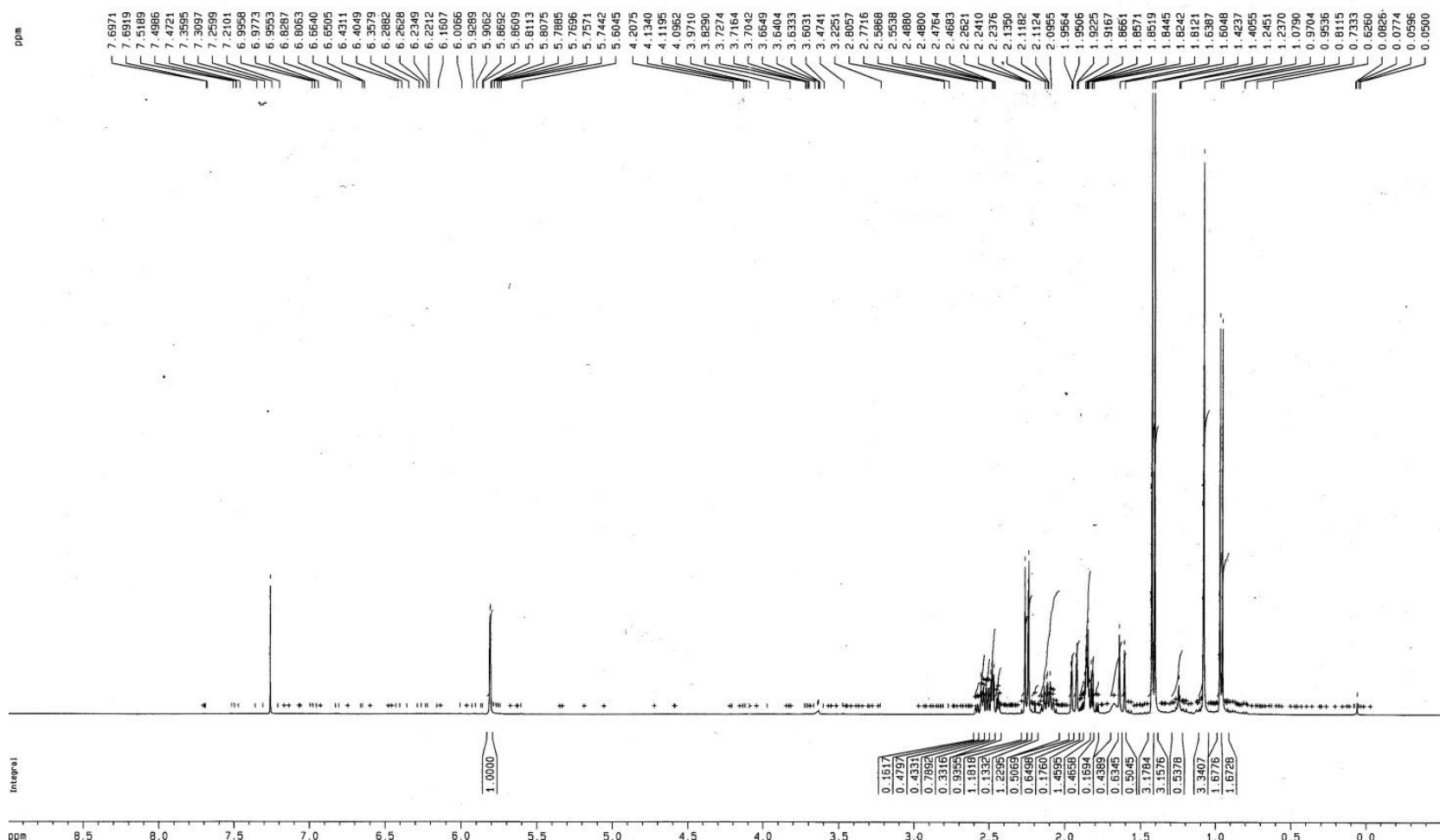

S8. ${ }^{13} \mathrm{C}$ NMR spectrum of the new compd. 2

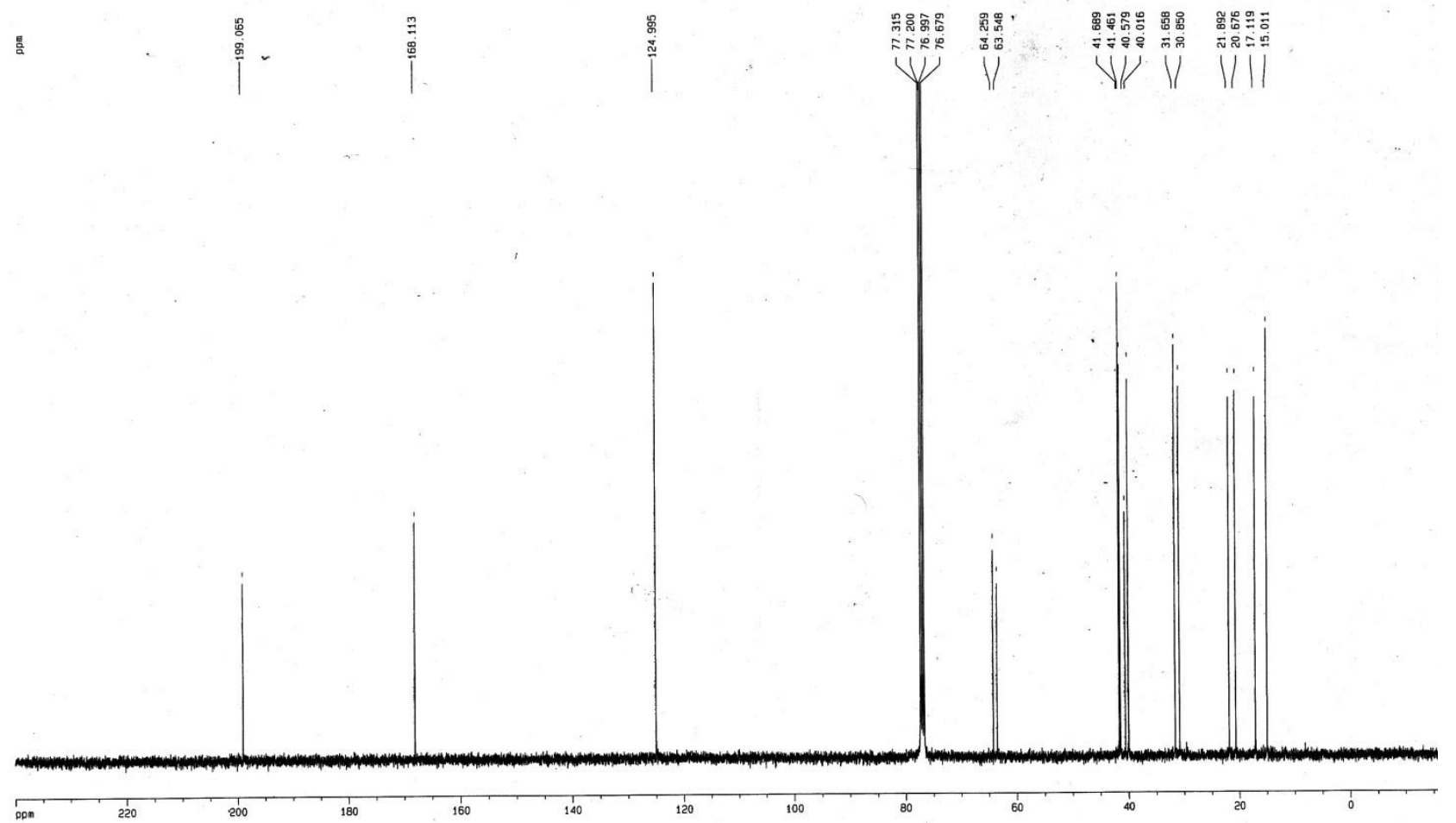



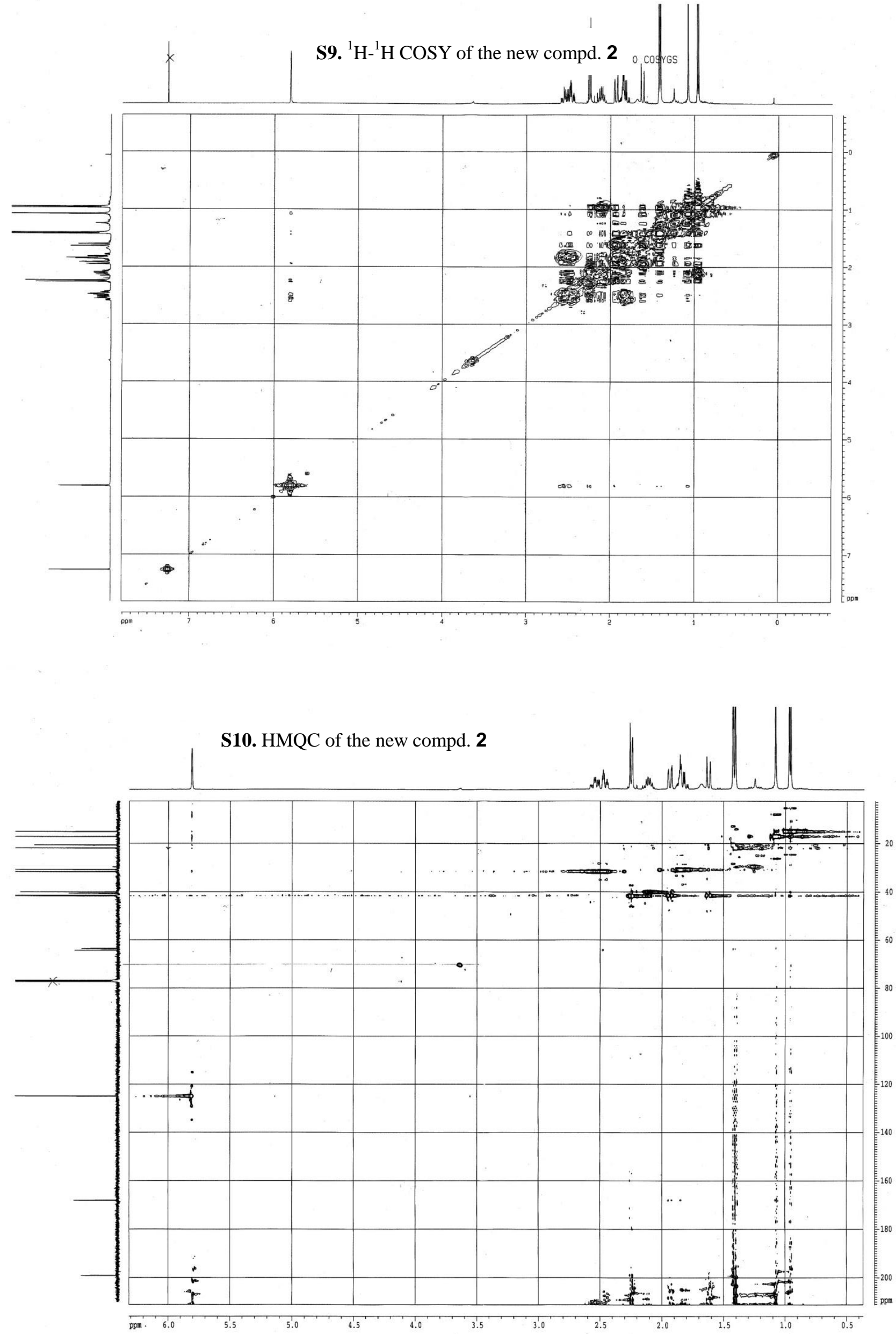

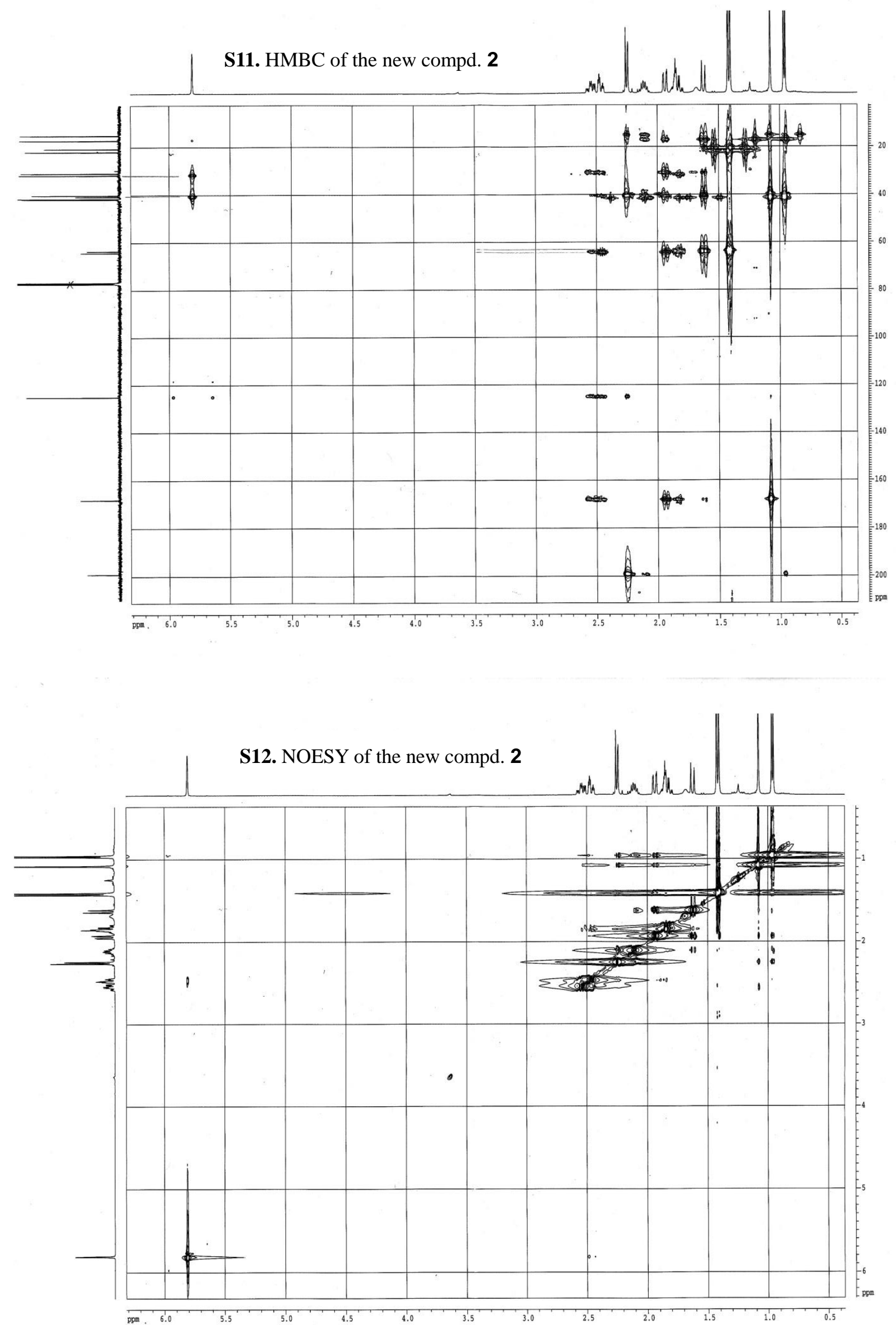
S13. ${ }^{1}$ H NMR spectrum of the new compd. 3

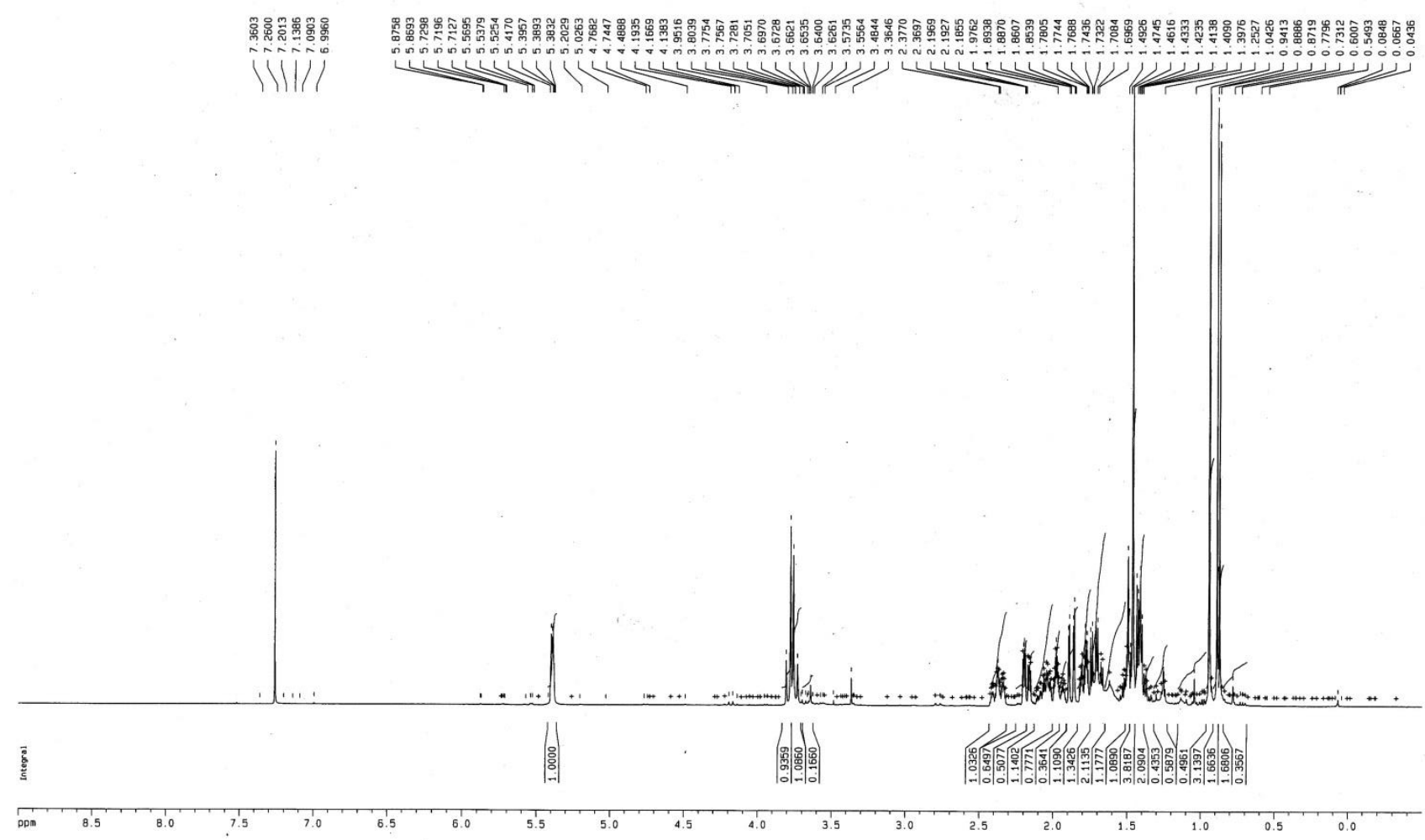

S14. ${ }^{13} \mathrm{C}$ NMR spectrum of the new compd. 3

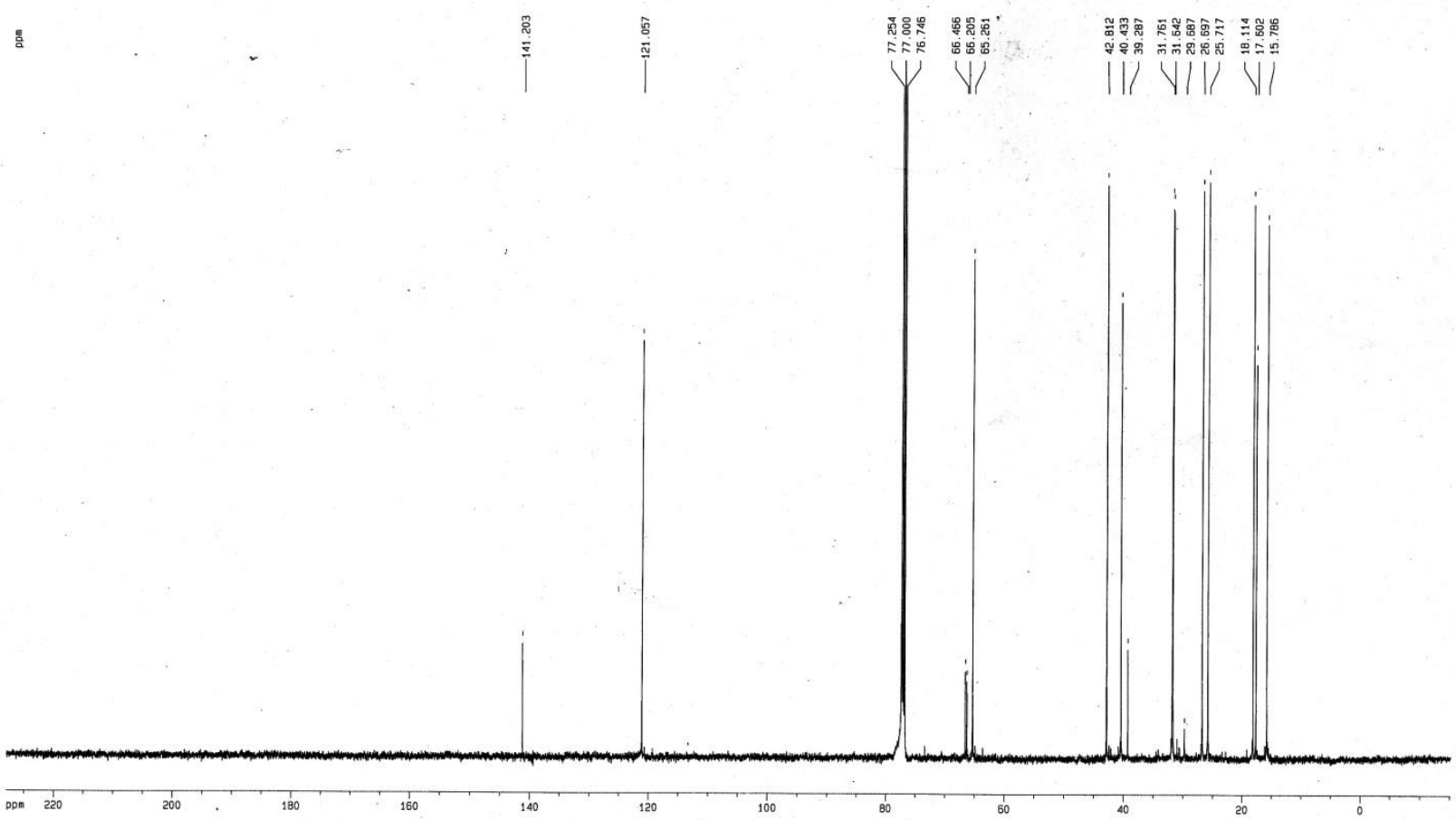



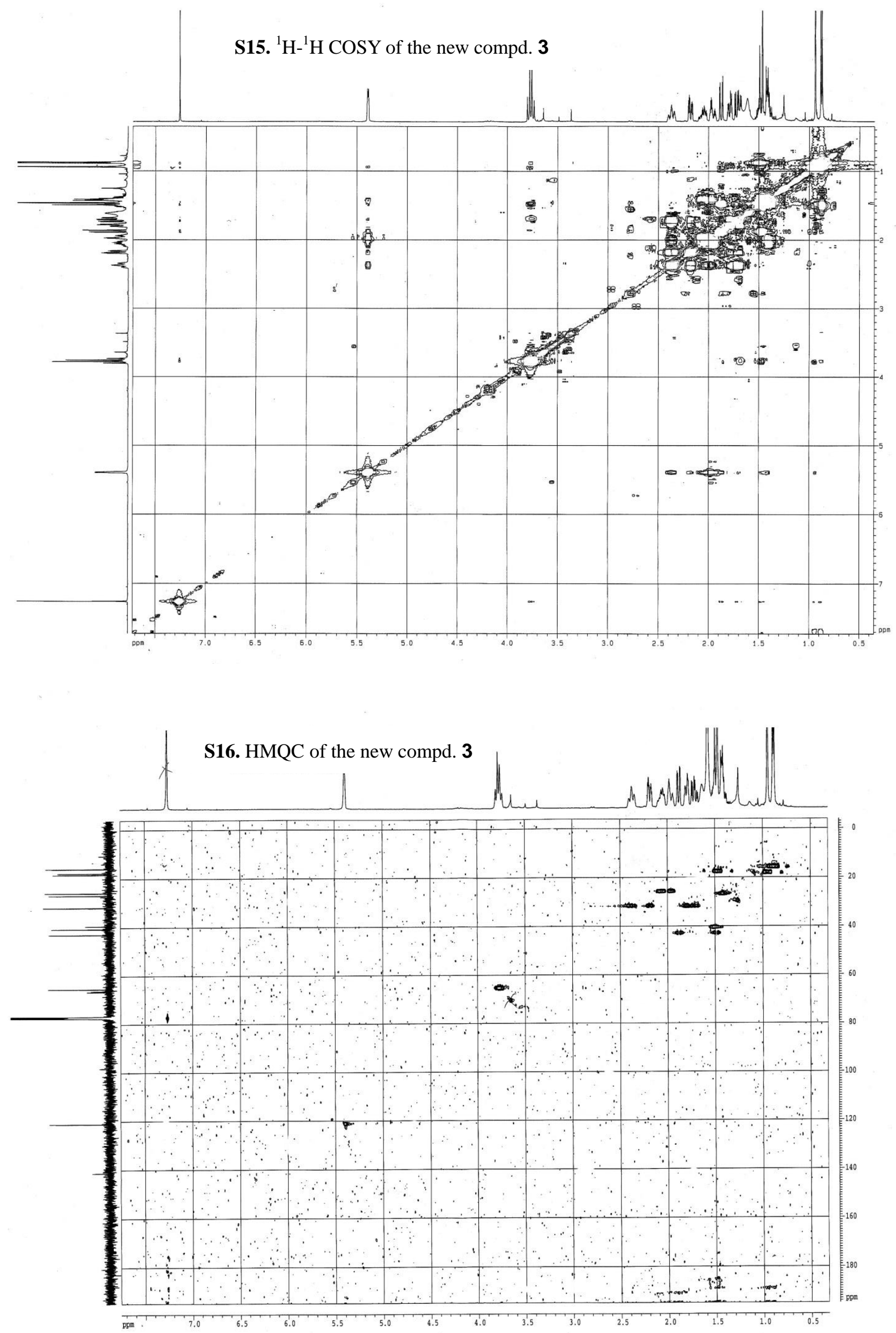

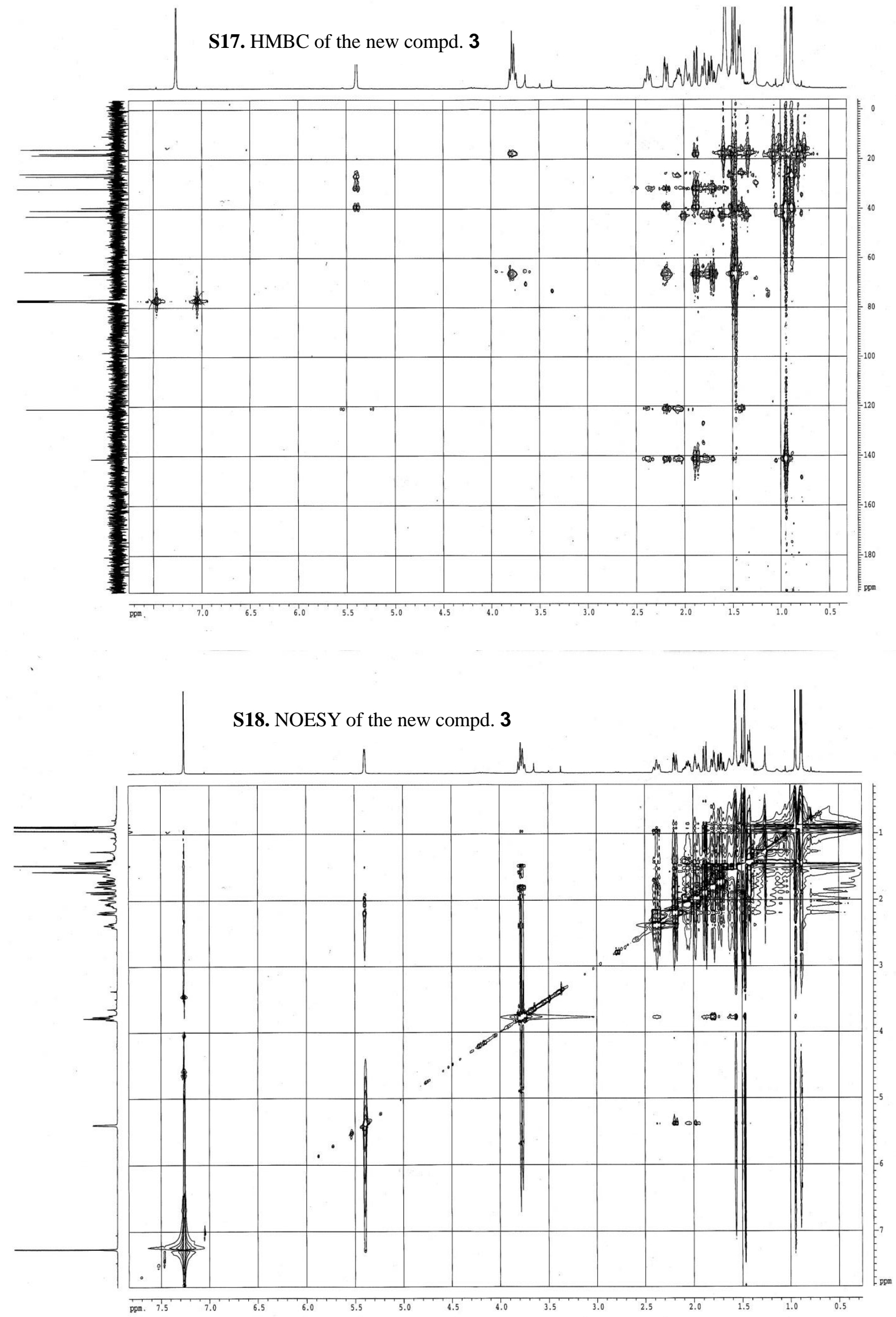
S19. The photograph of plant material

Vetiveria zizanioides roots were identified based on their morphological characteristics.

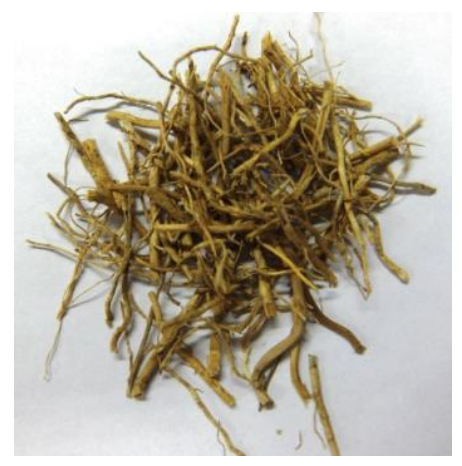

